$\mathrm{DOE} / \mathrm{CE}--0225$

DE88 013610

\title{
OPPORTUNITIES FOR SUPPORT OF GEOTHERMAL ENERGY ACTIVITIES FROM PETROLEUM VIOLATION ESCROW FUNDS
}

JUNE 1988

\section{U.S. DEPARTMENT OF ENERGY GEOTHERMAL TECHNOLOGY DIVISION WASHINGTON, D.C.}




\section{DISCLAIMER}

This report was prepared as an account of work sponsored by an agency of the United States Government. Neither the United States Government nor any agency Thereof, nor any of their employees, makes any warranty, express or implied, or assumes any legal liability or responsibility for the accuracy, completeness, or usefulness of any information, apparatus, product, or process disclosed, or represents that its use would not infringe privately owned rights. Reference herein to any specific commercial product, process, or service by trade name, trademark, manufacturer, or otherwise does not necessarily constitute or imply its endorsement, recommendation, or favoring by the United States Government or any agency thereof. The views and opinions of authors expressed herein do not necessarily state or reflect those of the United States Government or any agency thereof. 


\section{DISCLAIMER}

Portions of this document may be illegible in electronic image products. Images are produced from the best available original document. 
EXECUTIVE SUMMARY. . . . . . . . . . . . . . . . . . . . . . . . . ii

1.0 INTRODUCTION . . . . . . . . . . . . . . . . . . . . . . . . . . 1

2.0 BACKGROUND. . . . . . . . . . . . . . . . . . . . . . . . . . . 3

2.1 The Use of Exxon PVE Funds. . . . . . . . . . . . . . . . . . . 3

2.2 The Use of Stripper Well PVE Funds . . . . . . . . . . . . . . . 6

3.0 MONITORING AND OVERSIGHT OF EXXON AND STRIPPER WELL FUNDS . . . . . . . . . . . . . . . . . . . . 7

4.0 STATES' USE OF PVE FUNDS. . . . . . . . . . . . . . . . . . . . . . . 8

4.1 Exxon Funds . . . . . . . . . . . . . . . . . . . . . . . . . . 8

4.2 Stripper Well Funds . . . . . . . . . . . . . . . . . . . . 11

5.0 CONTACTS FOR FURTHER INFORMATION . . . . . . . . . . . . . 15

APPENDIX A - STATE ENERGY OFFICES . . . . . . . . . . . . . . . . . A-1 
The purpose of this document is to provide a reference for the geothermal community regarding the extent to which Petroleum Violation Escrow (PVE) funds might be employed by states to fund research, development, demonstration and applications pertaining to geothermal energy resources. The document highlights the background and status of the PVE funds being disbursed through state energy agencies and summarizes the types of energy-related activities being conducted with these funds and the processes used to select and approve these activities. These funds may provide a mechanism for expanding the contribution of geothermal technologies to domestic energy conservation and security.

To date approximately $\$ 3.6$ billion of PVE funds have been disbursed to state energy of fices for use in a variety of energy-related programs that mainly encourage energy conservation or the use of renewable energy. A majority of these funds resulted from two cases: the Exxon Decision and the Stripper Well Settlement Agreement. Opportunities for funding support of geothermal activities most likely derive from these two sources. However, it is anticipated that other settlements will result in additional funds being provided to the states that may be similarly used.

The specific allocation of these funds within various candidate state programs is left to the discretion of the individual state, but requires final review and approval of the Department of Energy (DOE) for consistency with the terms of the settlement agreements. A significant portion of these funds has already been committed for approved activities. However, the status of available (i.e., non-committed) funding varies among the states.

As discussed within this report, the PVE funds are administered by the state energy agencies within certain programs and approval limitations. Currently, two states (Colorado and South Dakota) are conducting geothermal projects using PVE funds. At least one other state (Arizona) has considered applying PVE funds to geothermal projects. However, other non-geothermal activities that are being conducted in several states represent types of projects that could be relevant to geothermal power production, district heating/cooling and/or direct use projects. These include:

- demonstrations of viable technologies for commercial applications, which may include feasibility studies, site location, acquisition, installation and operation of energy equipment

- demonstrations of energy savings through utilization of alternative energy resources, including assessments of the potential energy savings and feasibility of replacement technologies 
- district heating projects which could include feasibility studies, resource assessment and characterization, planning, engineering and other related aspects

- revolving fund programs to provide loans for residential renewable resource improvements as well as heating system replacements and improvements

- funding assistance to municipalities and businesses for assessments of the economic and technical feasibility of alternative energy technologies

- energy centers for conducting seminars, public education and outreach on energy management, efficiency and conservation, in which a geothermal component could be incorporated

- technology assistance centers or services to provide commerce and industries with energy analysis and on-site technical assistance, in which a geothermal component could be incorporated

The appropriate state energy office is the primary contact point to ascertain the funding availability and applicability as well as the acceptability of any candidate project. Inquiries regarding activities planned or underway within relevant states may also reveal other projects that could include geothermal components.

The DOE Geothermal Technology Division is available to provide technical assistance upon request by state energy of ficials for the review and evaluation of the technical viability of geothermal-related projects. 


\section{OPPORTUNITIES FOR SUPPORT OF GEOTHERMAL ENERGY ACTIVITIES FROM PETROLEUM VIOLATION ESCROW FUNDS}

\subsection{INTRODUCTION}

The United States imposed price controls on crude oil and petroleum products during the period of 1973 to 1981 . In the late 1970s, the Economic Regulatory Administration of the Department of Energy began to bring suit against a large number of oil companies for alleged overcharges during the period of price control. Since 1981, a number of these suits have been settled, and the funds have been held in Petroleum Violation Escrow (PVE) accounts for restitution to those consumers who were overcharged during the price-control era.

One of the early significant distributions of PVE funds was accomplished via an appropriations amendment introduced by Senator John Warner of Virginia. That amendment (Section 155 of Public Law 97-377, known as the "Warner Amendment") identified five existing federal programs that were designed to reduce some of the negative impacts of rising energy prices, and that were to be used to channel a portion of PVE funds to energy-related needs of the states. Early in the process, it was determined that it would be difficult to provide direct restitution to the average or small consumer. Therefore, during 1984 , the judge in one case decided that a significant portion of the PVE funds would be provided to the states for use in programs that would indirectly benefit those who had been overcharged.

Currently, PVE funds are being used by the states for a variety of energy-related programs. To date, approximately $\$ 3.6$ billion have been distributed to the states with a majority of the funds (approximately $\$ 3$ billion) being distributed under two cases: the Exxon Decision and the Stripper Well Settlement Agreement. In addition, it is anticipated that other settlements (including the recent Texaco settlement) will result in additional funds being provided to the states over the next few years. The states are using these funds to provide indirect restitution by implementing programs relating to:

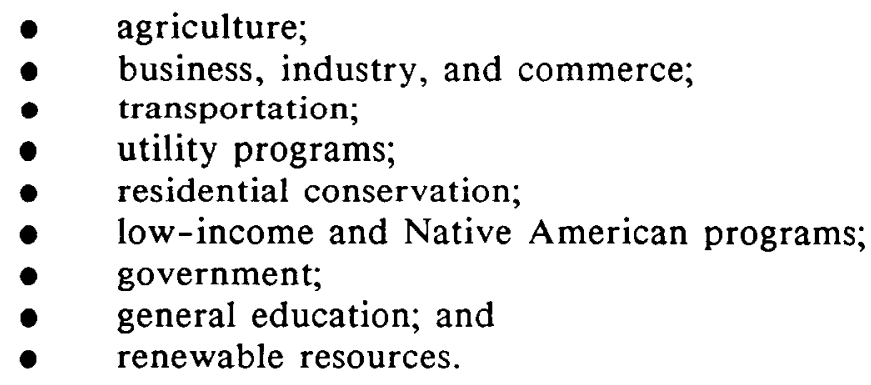

Settlements other than Exxon and Stripper Well are either narrowly defined or the funds have already been expended. Therefore, opportunities for funding support are most likely to reside in those two settlements. Further, there is greater flexibility under the Stripper Well program than the Exxon program, in which primarily two of the programs, the State Energy Conservation Program (SECP) and the Energy Extension Service (EES), 
encompass a broad enough range of options to include possible geothermal energy projects. The SECP and EES are discussed in the following section.

This report provides a brief background on the distribution of PVE funds, followed by descriptions of approved projects that directly involve or are similar to those that may be of interest to the geothermal energy community. Its purpose is to highlight PVE activities that potentially could be duplicated or developed for geothermal energy, when so decided and proposed by state authorities. 


\subsection{BACKGROUND}

Between 1973 and 1981, under the Emergency Petroleum Allocation Act of 1973, Public Law 93-159, as amended ( 15 U.S.C. Section 751 et seq.), price controls were placed on all domestic oil, with three exceptions: (1) "new oil," produced subsequent to the controls; (2) some "old oil," exempted to stimulate production; and (3) stripper wells, which produced less than ten barrels of oil per day.

Once price controls were imposed, prices for exempted oil averaged more than twice the allowable price for oil regulated by the price ceilings. This disparity, as well as the complexity of the law's applicability, led to allegations that petroleum companies were overcharging customers for oil. Court cases ensued seeking remedies for the alleged "oil overcharge violations," prompting court orders and settlements to determine the amount of overcharges to be refunded to the injured parties (purchasers of petroleum products).

Two of the largest settlements, Exxon and Stripper Well, established overall requirements for states' uses of PVE funds. For Exxon, funds were distributed to states under the terms of Public Law 97-377, Section 155 (The Warner Amendment). The Stripper Well Agreement allowed a broader application of PVE funds, and provided for future settlement monies from other overcharge cases as well as any accrued interest. Except for the funds from the Exxon Decision which were all distributed for state programs, the PVE funds were distributed first to specific parties such as utilities, retailers, transporters, etc., who could establish claims of injury, with the remainder divided equally between the Department of Energy (DOE) and the states. State distribution of funds was based on historical consumption trends of refined petroleum products during the period in which the price controls were in effect. Future monetary additions to the fund due to accrued interest and/or other overcharge settlements or orders will be distributed in the same manner. Selected requirements established by the Exxon and Stripper Well settlements are highlighted in Table 1 and are described briefly below.

\subsection{The Use of Exxon PVE Funds}

The Exxon Decision stated that the funds were to be expended in the same ways as the Warner Amendment (Section 155, part C), which requires states to use the funds "as if such funds were received under one or more energy conservation programs." "Energy conservation programs" are defined (in part (e)(2)) as:

- The Low-Income Home Energy Assistance Program (LIHEAP)(Public Law 97-35, Title XXVI) administered by the Department of Health and Human Services (HHS), which helps pay the fuel bills of low-income households. LIHEAP funds can also be used to provide energy emergency assistance, and (up to 15 percent of each state's allocation) can be used for weatherization of low-income homes.

- The state and local assistance programs administered by DOE. These programs are:

- The Weatherization Assistance Program (WAP)(Public Law 94-385, Sec. 411 et seq.), which increases the energy efficiency of residences occupied by lowincome citizens across the country, particularly the homes of the elderly and the handicapped. 
- The State Energy Conservation Program (SECP)(Public Law 94-163, Sec. 361 et seq.), which was established to promote energy efficiency planning and activities that would reduce the growth rate of energy demand in states.

- The Energy Extension Service (EES)(Public Law 95-39, Title V), which provides small-scale energy users with personalized energy conservation information and technical assistance.

- The Institutional Conservation Program (ICP)(Public Law 95-619, Sec. 301304 ), which provides matching grants to public and private nonprofit schools and hospitals to identify and implement appropriate energy conservation measures, including using renewables.

The Exxon Decision further provides that no funds shall be spent on administrative costs. 
TABLE 1

\section{HIGHLIGHTS OF USES FOR EXXON AND STRIPPER WELL FUNDS}

$\underline{\text { Exxon }}$

- Five Federal Energy Conservation Programs

- Low-Income Home Energy Assistance Program (LIHEAP)

- Weatherization Assistance Program (WAP)

- Institutional Conservation Program (ICP)

-- efficiency improvements in schools and hospitals

- Energy Extension Service (EES)

- - technology transfer information and training

- State Energy Conservation Program (SECP)

-. interest rate reduction and revolving loan programs for authorized program activities

-- demonstrations of authorized program activities or commercially-available technologies in a new place or different application

-- financial assistance demonstrations for established program activities

-- planning activities

-- feasibility studies
Stripper Well

- Includes the five Federal Energy Conservation Programs applicable to Exxon

- Transportation Programs*

- Motor Fuel and Re-cycling Programs

- Public Transportation Programs

- Alternative Transportation Fuel Programs

- Residential and Commercial Programs*

- Demonstration Projects

- Conservation Promotion

- Solar Demonstration Programs

- Solar Lending Programs

- Research and Demonstration Projects

- Energy Loans

- Renewable Programs (e.g., geothermal, biomass, cogeneration)

- Technical Assistance

- Capital Expenditures

- Administrative Expenses (limited)

- Does not Prohibit Research

- Does not permit funding for strictly research projects

* Not restricted to Federal Energy Conservation Program activities. 
The specific allocation of Exxon funds among these programs is left to individual state discretion. The states also determine, in accordance with DOE rulings and guidelines, the measures within the four DOE energy conservation programs for which the Exxon funds will be used. DOE then approves amendments to annual state plans, which incorporate the additional programs to be funded with Exxon monies. HHS has also provided similar guidance to states regarding allowable Exxon-funded LIHEAP activities.

\subsection{The Use of Stripper Well PVE Funds}

The Stripper Well Settlement Agreement provides that each state has the discretion to select among energy-related programs designed to benefit consumers of petroleum products within the state -- the same programs as under Exxon, and any other DOE approved programs as well. Specifically, the programs that may be funded under the Stripper Well settlement include:

- Those that have been approved by DOE's Office of Hearings and Appeals (OHA) pursuant to 10 C.F.R. Part 205, Subpart V;

- Those referenced in the consent order into which DOE entered in 1981 with Standard Oil Company of California (Chevron) (46 Federal Register 52221, October 21, 1981);

- The five energy conservation programs administered by DOE and HHS, including SECP, EES, ICP, WAP, and LIHEAP (required under Exxon); and

- Such other restitutionary programs as may be approved by the District Court.

Signatories to the final Settlement Agreement also agreed that an "equitable share" of the funds will benefit low-income consumers and Native Americans. To qualify as a lowincome program under this amendment to the final Stripper Well Settlement Agreement, a restitutionary program must provide benefits solely to low-income consumers, have an eligibility ceiling equal to or below that of the Low-Income Home Energy Assistance Act of 1981, and adhere to the criteria specified in the Settlement Agreement. Qualifying Native American programs must confer benefits upon tribal governments and their citizens. 


\subsection{MONITORING AND OVERSIGHT OF EXXON AND STRIPPER WELL FUNDS}

In accordance with the District Court's orders, DOE must exercise oversight responsibility for Exxon overcharge distributions and actively monitor the disbursement of these funds as though the funds were appropriated for the grant programs. The Department of Health and Human Services has the oversight and monitoring responsibilities for all PVE funds placed into the Low-Income Home Energy Assistance Program.

For Stripper Well funds, DOE has the responsibility to review state proposals and inform the states whether those proposals are consistent with the terms of the Stripper Well Settlement Agreement. Substantive program plans, as well as proposed administrative expenses, are reviewed. States must also report annually to the Court and to DOE on the use of all Stripper Well funds. These reports must be submitted within 30 days of the close of each state's fiscal year. DOE has developed a format for the report which will allow reports to be reconciled with the state's original plan. DOE will inform the Court of any cases in which funds appear to have been expended inconsistently with the terms of the Settlement Agreement. 


\subsection{STATES' USE OF PVE FUNDS}

When PVE funds were distributed, states began to develop plans and recommendations for how those funds should be spent within the regulations. The states took a variety of approaches to this planning process. In some states, advisory committees were formed to make recommendations. Many states held public hearings, while others undertook extensive coordination activities among state agencies, local governments, and other interested organizations within the state. In over half of the states, state legislative approval is required before funds can be allocated. In some of those states, the state legislatures meet once every two years, lengthening the planning and approval process within the state. Most states are planning to expend the funds over a multiyear period.

The processes used to select PVE programs and projects differ among states, and each state is responsible for developing its criteria for project selection. In evaluating the overall value of the numerous projects vying for PVE funds, many states use factors such as economic development, environmental and societal well-being, and industry sustainability (e.g., agriculture) in addition to energy savings potential. However, in order for the project to be approved, it must be presented as an energy-related project, with these other factors enhancing its attractiveness, viability, and public benefit. Therefore, when exploring opportunities for the use of PVE funds, it is important to determine, on a state-specific basis, the plans, processes, and criteria used to select PVE-funded programs and projects.

\subsection{Exxon Funds}

Under the provisions of the SECP and EES, states have undertaken a variety of activities with Exxon funds to provide indirect restitution to their citizens. Descriptions presented below highlight examples of the types of projects undertaken at least in part using Exxon funds. While these projects do not necessarily involve geothermal applications directly, they represent the types of activities that could also be directed towards geothermal energy projects.

\section{$\underline{\text { Arkansas }}$}

FLAT PLATE HEAT EXCHANGER DEMONSTRATION. A demonstration project will be funded at the University of Arkansas' Medical Science Campus. The project involves the use of a flat plate heat exchanger to provide free cooling.

MODELING AND FORECASTING OF STATE ENERGY USE AND NEEDS. Funding will be provided for sof tware and equipment for a modeling and forecasting program to compile energy statistics and to project production, consumption, and price of energy resources in Arkansas. This will also involve the collection and analysis of demographic data as it applies to targeting new, and evaluating existing programs.

CONTINGENCY FUND FOR FUTURE DEMONSTRATION PROJECTS. Funds will be provided for a contingency budget to fund anticipated demonstration projects during the current budget period as they are recommended by the Governor's Office. 


\section{Colorado}

INSTITUTIONAL LOAN PROGRAM -- SHARED-SAVINGS DEMONSTRATION. The Institutional Loan Program provides a demonstration of "shared-savings" financing for Colorado's public sector institutions. Funding will be provided to complete energy management projects and to procure energy management services on a demonstration basis with the repayment of the funding to come from the energy savings. This project is aimed at mitigating the impacts of increasing energy consumption.

DEMONSTRATION -- WASTE-TO-HEAT FACILITY. The Denver-Aurora Waste-toHeat Plant is a demonstration project that will be a model for local governments in Colorado. This project will offer an opportunity to prove that a well known technology is appropriate in our environment. This project will demonstrate the conversion of refuse into thermal energy for the heating and cooling of buildings and other commercial uses.

SOLAR COGENERATION DEMONSTRATION. Industrial Solar Technology Company will install and demonstrate a solar cogeneration system using parabolic trough concentrating collectors and a Rankine cycle power system to produce heat and electricity for the Adams County Detention Center in Brighton, Colorado. The program's information will be disseminated through press releases, public contact, presentations and site visits. There are also in-depth evaluation and monitoring procedures.

Idaho

LOW-INTEREST LOAN PROGRAM DEMONSTRATION. This element will provide low-interest financing for residential, commercial, public/institutional, agricultural and local government projects. This measure demonstrates a financing mechanism for the purpose of energy conservation to both public and private sectors. It provides borrowers with funds to install ECMs with payback periods of 10 years or less. Activities will include monitoring contracts with borrowers and reviewing applications to determine technical feasibility.

\section{Massachusetts}

ENERGY ADVISOR SERVICE - PERSONALIZED TECHNICAL ASSISTANCE. EAS is offering on-site analyses of energy improvements to individual businesses wherever they may be in the process of implementing energy-related improvements, evaluating alternatives, establishing priorities, and reviewing proposals. The objective is to provide companies with information and investments to increase efficiencies and profitability through energy management programs. 
$\underline{\text { Maryland }}$

SMALL-SCALE COGENERATION PROJECT DEMONSTRATION. A "neighborhood power plant" which has proven to be an effective energy conservation device in several other states, will be the first of its kind to be installed and operated in Maryland. This installation in Baltimore will demonstrate the value and costeffectiveness of small scale cogeneration to hundreds of YMCAs, schools, community facilities, and other medium-scale energy users.

$\underline{\text { Maine }}$

SUBSIDIZED LOW-INTEREST LOANS FOR BUSINESS, INDUSTRY, AND NONPROFIT ORGANIZATIONS. Funds will be used to promote and provide interest rate buy-downs on energy conservation loans to small businesses, industry and nonprofit organizations. The interest rate will be reduced to $3 \%$ on principal loaned from private banks. Loans will range from $\$ 3,000$ to $\$ 100,000$ with terms up to 10 years. Loan subsidies linked to a 10 -year payback would leverage as much as $\$ 8$ million.

\section{Michigan}

COMMERCIAL DEMAND-SIDE MANAGEMENT EVALUATION. MRC is acting as the corporate financial manager for the Michigan Electrical Options Study (MEOS). MRC will contract with other firms to evaluate the cost of a series of demand-side management resource options and their contribution to conserving electrical power and energy in Michigan's commercial sector.

\section{$\underline{\text { Minnesota }}$}

COMMUNITY ENERGY INITIATIVES. Minimum grants of $\$ 15,000$ will be awarded to 20 communities with Community Energy Councils (CECs) for the planning and implementation of local energy projects recommended by DEED. This is an expansion of an existing program which currently offers technical assistance to CECs.

\section{$\underline{\text { Pennsylvania }}$}

MUNICIPAL SOLID WASTE TO ENERGY DEMONSTRATION. Funding will be provided for a demonstration to do feasibility studies, site location and draft preliminary drawings for municipal solid waste to energy projects. 


\section{Rhode Island}

COGENERATION STUDY DEMONSTRATION. This program will fund the acquisition, installation, and operation of a $60 \mathrm{~kW}$ cogeneration system in each of four locations throughout the state. There will be provisions for public viewing and educational programs at the sites in order to show people the energy conservation and dollar savings benefits of cogeneration.

TECHNICAL ASSISTANCE TO COMMERCE AND INDUSTRY. The Governor's Office of Energy Assistance will contract with a number of consulting engineering firms to provide energy analysis and on-site technical assistance to commercial/industrial firms which apply for the service.

DOCKET INTERVENTION. This program will encourage energy conservation and energy efficiency among the state's utilities and the Public Utility Commission.

\subsection{Stripper Well Funds}

Following the distribution of funds under the Stripper Well Settlement Agreement, DOE established review procedures for state proposals. Generally, the procedures include:

- DOE review for consistency with Stripper Well Settlement Agreement;

- If found to be not consistent, a state may submit the proposal to the Office of Hearings and Appeals;

- If found to be consistent with the Stripper Well Settlement Agreement, and consistent with the provisions of the federal programs, a state may choose to include the project in the annual state plan;

- If the project is included in the annual plan for the federal program (e.g., SECP, EES, WAP, ICP), it is subject to the same reporting and monitoring requirements as appropriated grant funds; and

- A state may also implement the project without its inclusion in one of the federal programs, in which case the state must report annually on the use of the funds.

The following descriptions highlight approved projects funded, at least in part, with Stripper Well PVE funds. Some of the projects do include geothermal energy activities that could be duplicated elsewhere. Other projects include renewable energy projects, demonstration projects, and loan programs that may be applied to geothermal energy.

\section{Arizona}

THE SOLAR OASIS. As a demonstration of solar and energy conservation techniques, the Solar Oasis will display the latest technologies and serve as a study center for workshops, interactive computer networks, training programs, and other means to promote alternative energy sources. The City of Phoenix is donating land and providing initial planning. 
Colorado

CENTER FOR ENERGY MANAGEMENT. The Joint Center for Energy Management (JCEM), established at the Boulder Campus of the University of Colorado, will conduct seminars, expand its energy efficient light program, fund the assistantship program and set up a new energy lab, for an estimated savings of $\$ 29,500$ in 1989.

OURAY ENGINEERING CONSTRUCTION -- GEOTHERMAL HEATING DISTRICT. Funds will be used to pay for engineering work and other non-construction activities related to the establishment of a geothermal heating project in the West Slope city. A resource assessment will be conducted to confirm the existence of and to characterize the geothermal resource.

NORTH COLORADO MEDICAL CENTER -- GREELEY COGENERATION. Funds received by the North Colorado Medical Center in Greeley will be used to install a cogeneration project that is currently being designed.

ENERTECH THERMODYNAMICS INSTALLATION. Funds are being used on a feasibility study to demonstrate energy savings, by use of wind generators, to farm and ranch audiences. If the study proves successful, wind generators will be installed at three agricultural research stations in Eastern Colorado.

PLATTE RIVER POWER AUTHORITY -- PHOTOVOLTAICS. Funds are used by the Platte River Power Authority in the design, installation and monitoring of a 10 $\mathrm{kW}$ photovoltaic demonstration project. The project will compare different cell tracking and configurations and determine the feasibility of a utility scale array.

\section{$\underline{\text { Connecticut }}$}

ENERGY CONSERVATION LOAN INTEREST BUY-DOWN. The program provides a revolving fund to make loans for residential energy conservation, renewable resource improvements and heating system replacements and improvements.

COGENERATION FEASIBILITY STUDIES. This program will provide a complete engineering and economic analysis of cogeneration for hospitals, and state facilities.

DISTRICT HEATING FEASIBILITY STUDIES. Proposals will be accepted for district heating and for planning and engineering work.

\section{District of Columbia}

ENERGY CONSERVATION DEMONSTRATION PROGRAM. This program will provide financial assistance to individuals, businesses and organizations for conservation activities such as neighborhood energy fairs, workshops, seminars, and demonstrations of renewable resources and other energy efficient techniques and technologies. 
DATA REPOSITORY AND RESEARCH PROGRAM. DC Energy Office (DCEO) will develop and maintain a city-wide energy data repository and technical assistance service to educate the public on energy consumption patterns, and support the District's forecasting, reporting, and planning requirements.

\section{Georgia}

FEASIBILITY STUDIES FOR WASTE-TO-ENERGY FACILITIES. Georgia Department of Natural Resources (DNR), under contract to OER, will administer grants to local governments for feasibility studies of resource recovery facilities. Studies will be limited to energy conservation projects such as waste-to-energy plants that produce electricity or steam for sale or reuse.

\section{New York}

INSTITUTE ON SUPERCONDUCTIVITY. The New York State Energy Research and Development Authority will allocate funds to establish an institute to pursue applied research technology transfer and demonstration projects pertaining to high-temperature superconductors and related energy producing and conserving technologies. The institute will be located at the State University of New York at Buffalo.

\section{Oklahoma}

ENERGY RESEARCH OFFICE. Funding is being used to operate energy conservation or energy research offices. Grants will be made for conducting energy research.

OKLAHOMA UNIVERSITY ENERGY CENTER. Funding is being used to create an Energy Center to install energy conservation systems and to fund instrumentation equipment necessary to conduct research designed to conserve energy.

\section{$\underline{\text { South Dakora }}$}

HOT SPRINGS GEOTHERMAL HEATING AND COOLING. Funds will be used to provide a grant to the City of Hot Springs, South Dakota, to install a geothermal heating and cooling system in the new Hot Springs Civic Center being constructed in that city. The requested funds will be used to cover the direct cost of labor and materials to install the geothermal system.

\section{Wisconsin}

SUSTAINABLE AGRICULTURE, ENERGY EFFICIENT PROMOTION. This program focuses on analyzing, demonstrating, and publicizing the applicability of agronomic and management practices which reduce the use of fossil fuel inputs. Sustainable agriculture is the combination of practices which attempt to minimize energy and product inputs, and maximize self-sufficiency of the farm unit. 
WASTE-TO-ENERGY CONVERSION. This program provides cost-sharing grants to municipalities and businesses for assessments of the economic and technical

feasibility of waste-to-energy projects. Examples include: methane gas recovery

from wastewater treatment plants and landfill projects; and solid waste-to-energy plan development. 


\subsection{CONTACTS FOR FURTHER INFORMATION}

This document is intended to provide the geothermal community with sufficient understanding of PVE funds to be able to approach state energy agencies (Appendix A) for further information. The examples are presented for illustrative purposes only. Specific projects are selected by the states based on their needs and priorities.

The appropriate state energy agency is the place to start to ascertain the funding availability and applicability as well as the viability of any candidate project. Inquiries regarding activities planned or underway may also reveal projects that could include geothermal components.

The DOE Geothermal Technology Division is available to provide assistance to state energy agencies, upon their request, for the review and evaluation of the technical viability of geothermal related projects. 
APPENDIX A

STATE ENERGY AGENCIES

A-1 


\section{STATE ENERGY OFFICES}

Alabama Department of Economic and Community Affairs

P.O. Box 2939

Montgomery, AL 36015-0939

(205) 284-8952

Department of Community and Regional Affairs

949 East 36th Avenue, Suite 400

Anchorage, AK 99508

(907) 563-1955

Arizona Department of Commerce

State Capitol Tower

1700 West Washington, 5th Floor

Phoenix, AZ 85007

(602) 255-4955

Arkansas Energy Office

One State Capitol Mall

Little Rock, AR 72201

(501) 371-1370

California Energy Commission

1516 9th Street

Sacramento, CA 95814

(916) 920-6091

Colorado Office of Energy

Conservation

112 East 14 th Avenue

Denver, CO 80203

(303) 866-2507

Office of Policy and Management, Energy Division

80 Washington Street

Hartford, CT 06016

(203) $566-2800$

Division of Facilities

Management/Energy Office

P.O. Box 1401

Dover, DE 19901

(302) 736-5644
DC Energy Office

613 G Street, NW, 5th Floor

Washington, DC 20001

(202) $727-1800$

Governor's Energy Office

214 South Bronough

Tallahassee, FL 32399-0001

(904) 488-6764

Office of Energy Resources 270 Washington Street, SW

Suite 615

Atlanta, GA 30334

(404) 656-5176

Energy Program Administrator

State Energy Division

Department of Planning and

Economic Development

335 Merchant Street, Room 110

Honolulu, HI 96813

(808) 548-2306

Idaho Department of Water Resources

Resource Analysis Division

450 West State Street

Boise, ID 83720

(208) 334-3597

Department of Energy and

Natural Resources

325 West Adams Street, Room 300

Springfield, IL 62706

(217) $785-2800$

Department of Commerce

Division of Energy Policy

One North Capitol, Suite 700

Indianapolis, IN 46204-2243

(317) 232-8940

Iowa Department of Natural Resources

Wallace State Office Building

Des Moines, IA 50319

(515) 281-5154 
Research and Energy Analysis

Division

Kansas Corporation Commission

State Office Building, Fourth Floor

Topeka, KS 66612

(913) 296-5460

Department of Production and Utilization

Kentucky Energy Cabinet

P.O. Box 11888

Lexington, KY 40578

(606) 252-5535

Louisiana Department of Natural Resources

P.O. Box 44124

Baton Rouge, LA 70804

(504) $342-4506$

Office of Energy Resources

State House Station No. 53

Augusta, ME 04333

(207) 289-3811

Maryland Energy Office

301 W. Preston Street, Suite 903

Baltimore, MD 21201

(301) 255-1810

Massachusetts Executive Office of Energy Resources

Leverett Saltonstall Building

100 Cambridge Street, Room 1500

Boston, MA 02202

(617) 727-4732

Michigan Energy Administration

Michigan Department of Commerce

P.O. Box 30228

Lansing, MI 48909

(517) $373-9090$

Minnesota Department of Energy and Economic Development

900 American Center Building

150 East Kellogg Boulevard

St. Paul, MN 55101

(612) 297-6424
Mississippi Department of

Energy and Transportation

Dickson Building, Suite 300

510 George Street

Jackson, MS 39202

(601) 961-4733

Missouri Department of

Natural Resources

Division of Energy

P.O. Box 176

Jefferson City, MO 65101

(314) 751-4000

Department of Natural Resources and Conservation

1520 East Sixth Avenue

Helena, MT 59620

(406) 444-6697

Nebraska Energy Office

P.O. Box 95085

State Capitol Building, 9th Floor

Lincoln, NE 68509

(402) 471-2867

Nevada State Office of Community

Services

Capital Complex

Carson City, NV 89710

(702) $885-4990$

Governor's Energy Office

2 1/2 Beacon Street

Concord, NH 03301

(603) 271-2711

New Jersey Division of Energy

Planning and Conservation

101 Commerce Street

Newark, NJ 07102

(201) 648-2744

Energy and Minerals Department 525 Camino de los Marquez

Santa Fe, NM 87501

(505) 827-5950

New York State Energy Office

2 Rockefeller Plaza

Albany, NY 12223

(518) 474-4376 
North Carolina Department of

Commerce

Energy Division

P.O. Box 25249

Raleigh, NC 27611

(919) 733-2230

Office of Intergovernmental

Assistance

State Capitol Building

Bismarck, ND 58505

(701) 224-2094

Ohio Department of Development Community Development Division

P.O. Box 1001

Columbus, $\mathrm{OH}$ 43266-0101

(614) 466-7457

Oklahoma Corporation Commission 301 NW 63rd Street, \#130

Oklahoma City, OK 73116

(405) 521-3941

Oregon Department of Energy

625 Marion Street, NE

Salem, OR 97310-0831

(503) 378-4040

Governor's Energy Council

P.O. Box 8010

Harrisburg, PA 17102

(717) 783-9989

Governor's Office of Energy Assistance 275 Westminster Mall

Providence, RI 02903

(401) 277-3370

Governor's Division of Energy, Agriculture and Natural Resources 1205 Pendleton Street, 3rd Floor

Columbia, SC 29211

(803) 734-0445

South Dakota Energy Office

217 1/2 West Missouri

Pierre, SD 57501

(605) 773-3603
Tennessee Department of Economic and Community Development 320 6th Avenue, North, 6th Floor Nashville, TN 37219-5308

(615) 741-2994

Energy Management Center of the Governor's Office of Budget and Planning

P.O. Box 12428

Capitol Station

Austin, TX 78711

(512) 463-1931

Utah Energy Office

355 West North Temple

3 Triad Center, Suite 450

Salt Lake City, UT 84180-1204

(801) 538-5428

Department of Public Services

State Office Building

Montpelier, VT 05602

(802) 828-2811

Department of Mines, Minerals and Energy

2201 West Broad Street

Richmond, VA 23220

(804) 257-1310

Washington State Energy Office

FA-11

809 Legion Way, SE

Olympia, WA 98504

(206) 586-5000

Fuel and Energy Office

Governor's Office of and Community and Industrial Development 1426 Kanawha Boulevard, East Charleston, WV 25301

(304) 348-8860

Department of Administration Division of State Energy

P.O. Box 7868

Madison, WI 53707

(608) 266-7958 
Economic Development and

Stabilization Board

Herschler Building

3rd Floor, East Wing

Cheyenne, WY 82002

(307) 777-7284

Territorial Energy Office

Office of the Governor

Pago Pago, AS 96799

(684) 633-1306, 4136, 4137,

4138 (via Overseas Operator)

Guam Energy Office

P.O. Box 2950

Agana, GU 96910

(671) 472-8711

(Overseas Operator:

$9-0-11-671-734-4452$ or 4530 )

Office of Energy and Environment

P.O. Box 340

Saipan, CM 96950

(855) $099-7174$ or 7284

Office of Energy

P.O. Box 41089-Minillas Station

Santurce, PR 00940

(809) $726-4740$

Office of Planning and Statistics

Office of the High Commissioner

Trust Territory of the Pacific Islands

Saipan, CM 96950

(855) 099-9333, 9734, 9864

(via Overseas Operator)

Virgin Islands Energy Office

Room 233, Building 3, Lagoon Complex

Fredericksted, St. Croix

U.S. Virgin Islands 00840

(809) $772-2616$ 